\title{
An Examination of the Techno-pedagogical Education Competencies (TPACK) of Pre-service Elementary School and Preschool Teachers
}

\author{
Muhammet Özdemir \\ Correspondence: Muhammet Özdemir, Assist. Prof. Dr., Bulent Ecevit University, Eregli Faculty of Education, \\ Departmen of Elemantary Education, Turkey.
}

Received: July 14, 2016 Accepted: August 2, $2016 \quad$ Online Published: August 17, 2016

doi:10.11114/jets.v4i10.1816 URL: http://dx.doi.org/10.11114/jets.v4i10.1816

\begin{abstract}
The purpose of this study is to determine the technological pedagogical content knowledge of pre-service elementary school and preschool teachers. The fundamental problem of the study consists of the investigation of teachers' TPACK by their year of study and fields. This is a descriptive study. It was conducted using the survey model because it aimed to determine TPACK of the 995 pre-service elementary school and preschool teachers who participated in the study. They were in the departments of elementary school teaching and preschool teaching at three state universities in the spring term of the 2014-2015 academic year. The study found the means of junior (third year) and senior (fourth year) pre-service teachers in the departments of elementary school teaching and preschool teaching to be high. Their means were also high in the sub-dimensions of TPACK competence. The TPACK means of the pre-service elementary school and preschool teachers were found to be high. The TPACK means of senior pre-service elementary school and preschool teachers were determined to differ from those of junior pre-service preschool teachers. It can be stated that this difference resulted from technology and material development courses taken by the pre-service teachers in different semesters. Their pre-service education had positive effects on their TPACK. Providing pre-service technology education and practice as part of relevant courses will not be adequate. Along with the education, pre-service elementary school and preschool teachers should be provided with opportunities to use technology. These opportunities should go beyond the basis of courses that they take. It should be supplemented with practice in teaching practicum courses and should be included in practice evaluation forms as a criterion. The subdimensions of TPACK can be examined, and TPACK competency can be assessed in specific teaching programs in further studies.
\end{abstract}

Keywords: techno-pedagogical education competency, techno-pedagogy, pre-service elementary school teachers, pre-service preschool teachers

\section{Introduction}

Knowledge is not stable; new information is always added on the old information, providing individuals with information required by the time is among the primary aims of all educational systems. Scientific and technological developments have brought about a variety of changes in educational practices in the twenty-first century (Yilmaz, 2007).

These rapid and innovative changes in science and technology require individuals to have digital competence, the ability to use digital technologies effectively and efficiently with the aim of developing their life skills and fostering their knowledge capacity in society (Yavuz-Konokman, Yanpar-Yelken \& Sancar-Tokmak, 2013).

The use of technology in many areas and its rapid development reveal the requirement of national policies to arrange suitably for the preparation of a labor force that is competent to deal with these developments. Societies that are making efforts to become an information society are particularly expected to use technological devices well to access and use information (Simsek, Demir, Bagceci \& Kinay, 2013).

The development of information technologies creates opportunities to use innovations in teaching environments (Altan \& Tuzun, 2011). The integration of information and communication technologies into education is becoming more important every day with the effect of theoretical transformations and technological developments in the teaching and learning processes (Cuhadar, Bulbul \& Ilgaz, 2013). Yavuz-Konokman et al. (2013) claim that individuals should use technology effectively to access information, to comprehend and evaluate it, to spread it and to contribute the production of information. They also state that this can be put into practice by acquiring digital competence and 
regulating technology-based learning experiences. Kabakci-Yurdakul (2011) argued that the integration of technology into education is a sophisticated and multi-dimensional process that requires up-to-date technology and consideration of a variety of administrative, instructional and theoretical variables.

It is inevitable that educational systems will enable future generations to earn qualifications and prepare them for the conditions of the contemporary world (Simsek et al., 2013). Schools are fundamental building blocks that enable the objectives of education to be achieved, and planned changes and innovations should take place in schools first (Cuhadar et al., 2013). Although the need for technology in schools has been met, and individuals use technologies such as the internet more frequently, there are still a number of problems with the integration of technology and education (Kaya \& Dag, 2013).

As stated by Kabakci-Yurdakul, Odabasi, Kilicer, Coklar, Birinci and Kurt (2014), it should not be forgotten that providing classes with technological materials does not mean that it will increase the quality of the teaching and learning process. Stating that the type of individuals forming society is directly associated with the type of teachers in education, and that the importance of teachers for the education of individuals in society cannot be ignored, Yilmaz (2007) also argues that if the aim is to raise individuals for information society, teachers should be provided with an education that enables them to be role models for an information society.

Yilmaz (2007) and Yavuz-Konokman et al. (2013) note that there are several studies showing that education institutions have problems integrating technology into education because the competencies of teachers and pre-service teachers for using technology are low. Similarly, Kabakci-Yurdakul (2011) claimed that the insufficiencies of teachers in terms of knowledge, skill or competency are the leading obstacles to technology integration in literature.

Obstacles to the integration of technology in education have initiated a process that affects the development of technological integration models, causing integration models to change from technological models into pedagogical models. In other words, technological models aim to have teachers to acquire knowledge and skills about using technology, while pedagogical models are models that aim to have teachers to associate their technological knowledge with their pedagogical knowledge when teaching. One of the pedagogical models related to the integration of technology into education is the Technological Pedagogical Content Knowledge, TPACK model (Kabakci-Yurdakul, 2011).

The TPACK model was constituted by extending Shulman's pedagogical content knowledge (PCK) and adding technology to it (Mishra \& Koehler, 2006). Given the fact that the knowledge of teachers is special knowledge in the intersection of content and pedagogy, technology should not be considered as separate, but one of the inputs that shape this knowledge. This new term, which was derived from PCK, and defined as technological pedagogical content knowledge, is regarded as the foundation of effective teaching that benefits from technology (Mishra \& Koehler, 2006). TPACK includes the presentation of concepts using technology: knowledge about using technology constructively to teach content, knowledge about what complicates or facilitates learning concepts, knowledge about the ways technology can help students comprehend difficult subjects, knowledge about the ways knowledge and technologies are used to add new information to current information, to develop new epistemology or to foster existing information about students' present knowledge and epistemology (Mishra \& Koehler, 2006).

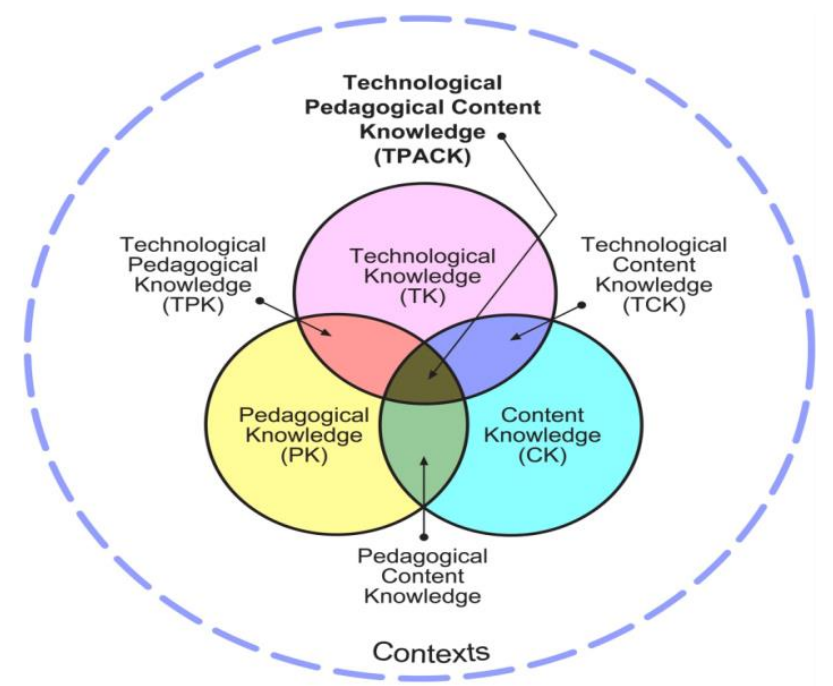

Figure 1. The Dimensions of the Technological Pedagogical Content Knowledge Approach (Koehler \& Mishra, 2009) 
As indicated in Figure 1, the Technological Pedagogical Content Knowledge approach has three main components including content knowledge, pedagogical knowledge and technological knowledge, and their intersection constitutes three sub-components: pedagogical content knowledge, technological pedagogical knowledge, and technological content knowledge. The intersection of all three components is the Technological Pedagogical Education approach (Koehler \& Mishra, 2009).

Using technology has recently become a requirement in educational environments. Educational institutions and teachers should keep pace with this change.

Technology is used for research, PowerPoint presentations, data collection for a project and more. There are a variety of perspectives on using it in education (Argon, Ismetoglu \& Yilmaz, 2015). Mazman and Kocak-Usluel (2011) observe that fostering and increasing students' learning with technology is emphasized by some definitions, while teachers' being able to use technology effectively or making technology a part of teaching programs is stressed by others. It is essential for teachers to be well-educated and to benefit from developments in science and technology to maintain their professional qualifications (Yilmaz, 2007).

Teachers' using technology effectively and purposefully will facilitate raising technologically literate individuals. Therefore, it is inevitable for qualifications that teachers and pre-service teachers will have to change. According to studies conducted on TPACK with teachers and pre-service teachers, TPACK is important for the education of teachers and their professional development (Koehler \& Mishra, 2005). Teachers and pre-service teachers, the designers of learning environments, are expected to have technological pedagogical content knowledge (TPACK). Therefore, the determination of pre-service teachers' perceptions about their TPACK levels is very important (Yavuz-Konokman et al., 2013).

Studies in the literature examine teachers' technological pedagogical competencies, TPACK tendencies and relevant opinions (Kramarski \& Michalsky, 2010; Archambault \& Barnett, 2010; Bowers \& Stephens, 2011; Argon et al., 2015; Kabakci-Yurdakul et al., 2014), the technological pedagogical competencies of instructors (Simsek et al., 2013), the relationship between pre-service teachers' technological pedagogical competencies, their use of communication technologies and their individual innovativeness (Koehler \& Mishra, 2005; Schmidt et al., 2009; Jamieson, Finger \& Albion, 2010; Kabakci-Yurdakul, 2011; Cuhadar et al., 2013). Gur \& Karamete (2015) argue that further studies should be conducted to determine pre-service teachers' TPACK and support the development of their TPACK. Baran and Bilici (2015) noted that studies conducted on pre-service teachers and TPACK concentrate most on elementary school teaching. The number of studies of TPACK was determined to be only two by a review studies of pre-service preschool teachers in the national and international literature (Usluel, Ozmen \& Celen 2015; Baran \& Bilici 2015). Voogt et al. (2013) remarked that technological content knowledge has a discipline-based knowledge structure, and it should be defined separately for different disciplines. In the light of this information, this study was planned to contribute to the study of pre-service preschool teachers and TPACK. Since elementary school teaching is regarded as the closest discipline to preschool teaching in basic education, the study was arranged as an interdisciplinary study of TPACK on pre-service elementary school and preschool teachers and took its final form. Thus, determining the technological pedagogical content knowledge of pre-service elementary school and preschool teachers was the aim of this study. Through this overall aim of the current research, the following questions of the research were: addressed

1. Do the TPACK competencies of pre-service elementary school teachers differ significantly by year of study?

2. Do the TPACK competencies of pre-service preschool teachers differ significantly by year of study?

3. Do the TPACK competencies of pre-service elementary school and preschool teachers differ significantly by year of study?

4. What is the distribution of pre-service elementary school and preschool teachers' TPACK sub dimension competencies by year of study?

\section{Method}

\subsection{Research Design}

The study was conducted using the survey model because its aim was to determine the TPACK of pre-service teachers in the departments of primary school elementary school teaching and preschool teaching in their third and fourth years of study at three different universities. The survey design provides a quantitative or numeric description of attitudes or opinions of a population by studying a sample of that population. Results of sample, researcher generalizes or draws inferences to the population. Survey research is appropriate for descriptive analysis of large samples. A survey is a non-experimental fixed design, usually cross-sectional in type. Moreover, it is a research approach that aims to describe previous or existing cases as they are (Babbie, 1990; Creswell, 2014, Robson \& McCartan, 2016). This method attempts to define the case, individual or object that is the subject of study in its own conditions and as it is. No effort can be 
made to change and to affect them in any way. Controlled generalizations about scientific observations, records, the determination of relationships between cases and fixed principles are made in the descriptive survey model (Yildirim \& Simsek, 2000). According to Gall, Borg \& Gall (1996), the aim of the survey model is to explain the relationship between different educational cases by observing them carefully. Collecting a relatively large number of individuals' (which is selected through representative samples of individuals from known populations) small amount of datas by a standardized form, using a fixed design are the characteristics of the survey model (Robson \& McCartan, 2016).

\subsection{The Subject of the Research}

The study population consists of 995 junior and senior pre-service teachers in the departments of elementary school teaching and preschool teaching at Bulent Ecevit University, Gazi University, and Mugla University in the spring semester of the 2014-2015 academic year. The study was conducted at three different state universities to ensure that the university entrance exam (YGS) scores of the teachers were high, medium and low. These scores are displayed in Table 2.

Table 1. The Distribution of Pre-Service Teachers by University

\begin{tabular}{|c|c|c|c|c|c|}
\hline \multirow{3}{*}{ UNIVERSITY } & \multicolumn{5}{|c|}{ DEPARTMENT } \\
\hline & \multicolumn{2}{|c|}{ CLASSROOM TEACHING } & \multicolumn{3}{|c|}{$\begin{array}{l}\text { PRESCHOOL } \\
\text { TEACHING }\end{array}$} \\
\hline & Junior & Senior & Junior & Senior & Total \\
\hline Gazi University & 30 & 110 & 99 & 74 & 313 \\
\hline Mugla University & 36 & 89 & 50 & 112 & 287 \\
\hline Bulent Ecevit University & 74 & 135 & 95 & 91 & 395 \\
\hline Total & 140 & 334 & 235 & 277 & 995 \\
\hline
\end{tabular}

According to Table 1, 395 pre-service teachers in the department of elementary school and preschool teaching at Bulent Ecevit University, 313 pre-service teachers in the department of elementary school and preschool teaching at Gazi University, and 287 pre-service teachers in the department of elementary school and preschool teaching at Mugla University constitute the study sample.

Table 2. The Distributions of University Entrance Exam (YGS) Scores of the Study Group by University

\begin{tabular}{|c|c|c|c|c|}
\hline \multirow{3}{*}{ UNIVERSITY } & \multicolumn{4}{|c|}{ DEPARTMENT } \\
\hline & \multicolumn{2}{|c|}{ CLASSROOM TEACHING } & \multicolumn{2}{|c|}{$\begin{array}{l}\text { PRESCHOOL } \\
\text { TEACHING }\end{array}$} \\
\hline & Junior & Senior & Junior & Senior \\
\hline Gazi University & 391 & 416 & 395 & 433 \\
\hline Mugla University & 372 & 406 & 351 & 430 \\
\hline Bulent Ecevit University & 363 & 394 & 352 & 418 \\
\hline
\end{tabular}

Simple random sampling was used to select the sample. Simple random sampling method is a way to select a smaller group or sample from a large universe for examination. It is based on the assumption that individuals in sample are homogeneous. Researchers can select individuals that they can easily reach in the sample. Every individual in the universe has an equal chance of belonging to the sample (Easton \& McColl, 1997; Cohen, Manion \& Morrison, 2003).

\subsection{Data Collection}

The Technological Pedagogical Education Competency Scale developed by Yurdakul et al., (2012) was administered to the pre-service elementary school and preschool teachers for data collection.

The scale consists of four sub-headings to determine the TPACK competencies of pre-service teachers. The four sub-headings include design, practice, ethics and specialization.

The scale items are in type of 5-point Likert scale. The categories of scale were: I definitely can't do this, I can't do this, I can do this partially, I can do this, and I can do this easily. The TPACK scale consists of 33 items. The highest possible score on the scale is 165 , and the lowest score is 33. Its internal consistency coefficient (Cronbach's alpha coefficient) was found to be .96 . The internal consistency coefficients (Cronbach's alpha coefficient) of the factors that constitute the scale range from .85 to .92 . Confirmatory factor analysis validated the scale's four-factor structure. Also, the test-retest coefficient of the scale was found to be .80 . The point scoring for the scale's subdimensions is displayed in Table 3 .

Table 3. The Values of the Scale's Subdimensions

\begin{tabular}{ll}
\hline SUBDIMENSIONS & SCORES \\
\hline I definitely can't do this. & $0-1$ \\
I can't do this. & $1.1-2$ \\
I can do this partially. & $2.1-3$ \\
I can do this. & $3.1-4$ \\
I can do this easily. & $4.1-5$ \\
\hline
\end{tabular}


Table 4. The TPACK Scale Mean Scores of Students by University

\begin{tabular}{lllll}
\hline & \multicolumn{2}{l}{ DEPARTMENT } & \\
\hline UNIVERSITY & \multicolumn{2}{l}{ ELEMENTARY TEACHING } & \multicolumn{2}{l}{ PRESCHOOL TEACHING } \\
& Junior & Senior & Junior & Senior \\
Gazi University & 130.13 & 129.22 & 129.15 & 131.94 \\
Mugla University & 129.08 & 134.80 & 124.34 & 132.73 \\
Bulent Ecevit University & 130.04 & 135.22 & 131.64 & 136.58 \\
\hline
\end{tabular}

According to Table 4, the TPACK scale mean score of the senior pre-service teachers in the department of preschool teaching at Bulent Ecevit University was the highest, 136.58, while the lowest mean score, 124.34 was obtained by the junior pre-service teachers in the department of preschool teaching at Mugla University.

The research data were collected in the spring semester of the 2014-2015 academic year. The pre-service teachers were provided with detailed information about the study before the scale was administered. Twenty minutes were granted for the students to complete the scale. The research data were collected by the researcher at Bulent Ecevit University and by lecturers in the departments where the study was conducted at Gazi and Mugla Sitki Kocman University.

\subsection{Data Analysis}

The data obtained from the Technological Pedagogical Education Competency Scale were loaded into the SPSS 17 package program. The percentage frequency distribution of the data was determined by the sub-problems of the study. The independent samples t-test and one-way variance analysis (ANOVA) were conducted.

\section{Results}

a). The independent samples t-test was performed to answer this sub-question, "Do the TPACK competencies of pre-service elementary school teachers differ significantly by year of study?"

Table 5. The independent samples t-test results of pre-service elementary school teachers' TPACK by year of study

\begin{tabular}{clllll}
\hline Year of Study & $\mathrm{N}$ & $\overline{\mathbf{X}}$ & $\mathrm{SS}$ & $\mathrm{t}$ & $\mathrm{p}$ \\
\cline { 2 - 3 } & 140 & 129.82 & 15 & -1.88 & 0.60 \\
Senior & 334 & 133.13 & 18 & & \\
& & & & &
\end{tabular}

According to Table 5, the mean scores of Technological Pedagogical Education Competency scale were determined to be $=129.82$ for the junior pre-service teachers studying elementary school teaching, and 133.13 for the senior pre-service teachers studying elementary school teaching. According to the T value and 95\% confidence interval $(\mathrm{p}<0.05)$, there was no significant difference between the Technological Pedagogical Education Competency scores of the two groups.

b). The independent samples t-test was performed to answer the sub-question, "Do the TPACK competencies of pre-service preschool teachers differ significantly by year of study?" a).

Table 6. The independent samples t-test results of pre-service preschool teachers' TPACK by year of study

\begin{tabular}{clllll}
\hline Year of Study & $\mathrm{N}$ & $\overline{\mathbf{X}}$ & $\mathrm{SS}$ & $\mathrm{t}$ & $\mathrm{p}$ \\
\hline Junior & 244 & 129.13 & 16 & -3.16 & $0.02^{*}$ \\
Senior & 277 & 133.78 & 16 & & \\
\hline
\end{tabular}
$* \mathrm{p}<0.05$

According to Table 6, the mean scores of Technological Pedagogical Education Competency scale were determined to be $=129.13$ for the junior pre-service teachers studying preschool teaching, and $=133.78$ for the senior pre-service teachers studying preschool teaching. According to the $\mathrm{T}$ value and $95 \%$ confidence interval $(\mathrm{p}<0.05)$, there was a significant difference between the Technological Pedagogical Education Competency scores of the junior and senior pre-service preschool teachers.

c). The ANOVA test was performed to answer the sub-question, "Do the TPACK competencies of pre-service elementary school and preschool teachers differ significantly by year of study?"

Table 7. The Independent Samples Variance Analysis of Pre-service Elementary School and Preschool Teachers' TPACK by Year of Study

\begin{tabular}{llllll}
\hline Source of Variance & $\begin{array}{l}\text { The Sum of } \\
\text { Squares }\end{array}$ & Sd & $\begin{array}{l}\text { The Mean } \\
\text { Squares }\end{array}$ & off & p \\
\hline Intra-groups & 3,967 & 3 & 1,322 & 4.53 & $0.004^{*}$ \\
Between-groups & 289,277 & 991 & 291 & & \\
Total & 293,244 & 994 & & & \\
$* \mathrm{p}<0.05$ & & & &
\end{tabular}


According to Table 7, there was a significant difference between the pre-service teachers' TPACK by year of study (F ( 3 , $991)=4.53, \mathrm{p}<0.05$ ). In other words, the pre-service teachers' TPACK varies significantly by their year of study.

Tukey analysis was carried out to find between which groups the differences of pre-service teachers' TPACK exist. The results of Tukey analysis are displayed in Table 8.

Table 8. The Tukey Analysis Results for the Independent Samples of Pre-service Elementary School and Preschool Teachers' TPACK by Year of Study

\begin{tabular}{lllllll}
\hline Department & & X & S & f & p & Difference (Tukey) \\
\hline Elementary Teaching Junior & $(1)$ & 129.8 & 15.7 & 4.5 & .004 & \\
Elementary Teaching Senior (2) & 133.1 & 18.1 & & & $2-3$ \\
Preschool Teaching Junior & $(3)$ & 129.1 & 16.7 & & & $4-3$ \\
Preschool Teaching Senior & (4) & 133.7 & 16.7 & & & \\
\hline
\end{tabular}

Table 8 shows that the mean scores of senior pre-service elementary school teachers $(x=133.1)$ differed significantly from those of junior pre-service preschool teachers $(\mathrm{x}=129.1)$ at the level of 0.05 .

According to Table 8, it was determined that the mean score of senior pre-service teachers studying preschool teaching $(\mathrm{x}=133.7)$ was significantly different from the mean score of junior pre-service teachers studying preschool teaching $(\mathrm{x}=129,1)$ at the level of 0.05 .

d). The TPACK subdimension mean scores of the pre-service teachers were calculated to answer the sub-problem, "What is the distribution of pre-service elementary and preschool teachers' TPACK sub dimension competencies by year of study?"

Table 9. The TPACK Subdimension Mean Score Results of Pre-Service Elementary and Preschool Teachers by Year of Study

\begin{tabular}{lllll}
\hline Department & DESIGN & PRACTICE & ETHICS & SPECIALIZATION \\
\hline Elementary Teaching Junior & 3.90 & 4.01 & 4.18 & 3.79 \\
Elementary Teaching Senior & 4.12 & 4.22 & 4.21 & 4.09 \\
Preschool Teaching Junior & 3.84 & 3.92 & 3.96 & 3.71 \\
Preschool Teaching Senior & 4.10 & 4.15 & 4.20 & 3.90 \\
\hline
\end{tabular}

When the TPACK sub-dimension (see Table 3 for the levels) mean scores of pre-service teachers were examined according to Table 9, the levels of junior pre-service elementary teachers and junior and senior pre-service preschool teachers were found to be at the "I can do this" level of competence. The senior pre-service elementary teachers were determined to be at the "I can do this" level of competence for the design and specialization subdimensions and at the "I can do this easily" level for the ethics subdimension.

\section{Discussion and Conclusion}

The aim of this study was to determine whether the TPACK competence levels of the pre-service elementary and preschool teachers show any difference by year of study and departments.

The means of junior and senior pre-service teachers' TPACK competencies, studying at the department of elementary school teaching and preschool teaching were found to be high. Like the results of the relevant studies, the pre-service teachers stated that they feel competent in terms of technological pedagogical education (Koehler \& Mishra, 2005; Schmidt et al., 2009; Jamieson, Finger \& Albion, 2010; Kabakci Yurdakul, 2011; Kaya et al., 2011; Sancar Tokmak, Yavuz Konokman \& Yanpar Yelken, 2013; Yavuz Konokman et al., 2013; Ozturk, 2013; Sad, Acikgul \& Delican, 2015).

No statistical difference was found between the mean scores of the technological Pedagogical competencies of junior and senior pre-service elementary school teachers. Kula (2015) stated that there was no significant difference between the years of study which are close to each other.

A statistical difference was found between the mean scores of the technological pedagogical competencies of junior and senior pre-service preschool teachers. In their study of sophomore, junior and senior pre-service preschool teachers' TPACK levels, Sancar Tokmak, Yavuz Konokman and Yanpar Yelken (2013) found that mean scores varied by year of study, like this study. Kula (2015) found that more years of study increase the TPACK means of pre-service teachers. As their years of study increase, the TPACK means of pre-service teachers change. Yavuz Konokman et al. (2013) stated that the TPACK competence perceptions of pre-service teachers in senior year were high because they had attended most of the technology, pedagogy and major area courses. This study's results can be interpreted in a similar way.

In statistical analysis, the TPACK competencies of senior pre-service preschool and elementary school teachers were determined to show difference statistically from those of junior pre-service preschool teachers. Kula (2015) found that as years of study increase, the TPACK means of pre-service teachers increase. Moreover, in their study determining the TPACK competencies of teachers in different fields, Kazu \& Erten (2014) found that the TPACK competence levels of 
elementary school teachers were higher than those of teachers in other fields.

The TPACK competence subdimension means of pre-service teachers in the study were determined to be at high levels. The results of this study are similar to those of the study by Yurdakul (2011) that investigated pre-service teachers' use of technological pedagogical competencies. The pre-service teachers were determined to feel competent in the design, practice and ethics subdimensions at a high level, while they felt competent in the specialization subdimension at a moderate level. Haslaman, Kuskaya-Mumcu \& Usluel (2007) found that the pre-service teachers felt competent in their technological content knowledge at high levels.

TPACK emerged recently, and studies of it have been conducted in many different fields. Studies have been conducted with pre-service teachers in particular. Especially mathematics and elementary school teaching have been at the forefront of studies conducted with pre-service teachers (Baran \& Bilici, 2015). The TPACK competencies of pre-service elementary school teachers have been found to have positive or high means. The TPACK competencies of the pre-service elementary school teachers in this study's sample have high means. There are two studies conducted with pre-service preschool teachers as the study group in the literature (Usluel, Ozmen \& Celen, 2015; Baran \& Bilici, 2015). According to the results of this study, the TPACK competencies of pre-service preschool teachers were high for both years of study; however, there was a difference in favor of senior pre-service teachers. The facts that these pre-service teachers had attended most of the senior year courses and that the material development course is given in the preschool teaching department in the sixth semester may have caused this. The scores of the pre-service elementary school teachers did not vary by year of study, and this may be because they took the material development course in the fourth semester.

Teachers give children their first information about many subjects during their time in the preschool and elementary educational system. Given that children start using technology at early ages, individuals who are or will be teachers in these fields should adequately integrate their content knowledge with technology. Teacher education programs play an important role for pre-service teachers to learn the knowledge required to integrate technology into their teaching skills (Hofer \& Grandgennett, 2012). Providing the necessary pre-service education is essential for using technology in educational environments. Harris, Mishra \& Koehler (2009) determined that the TPACK model fulfills teachers' technological, pedagogical and content needs and contributes to their professional developments. Pre-service education for teachers also has positive effects on their TPACK. Providing pre-service technology education and practice as part of the relevant courses will not be adequate. Along with the education, pre-service elementary school and preschool teachers should be provided with opportunities to use technology. These opportunities should go beyond coursework. It should be supplemented with practice in teaching practicum courses and included on practice evaluation forms as a criterion. The subdimensions of TPACK can be examined and TPACK competency can be assessed for specific teaching programs in further studies.

\section{References}

Altan, T., \& Tuzun, H. (2011). Teknoloji-zengin bireysel ogrenme ortamlarinin Fatih projesindeki yeri. Akademik Bilisim'11-XIII. Akademik Bilisim Konferansi Bildirileri, Inonu Universitesi, Malatya.

Archambault, L. M., \& Barnett, J. H. (2010). Revisiting technological pedagogical content knowledge: Exploring the TPACK Framework. Computers \& Education, 55(4), 1656-1662. http://dx.doi.org/10.1016/j.compedu.2010.07.009

Argon, T., Ismetoglu, M., \& Yilmaz, D. C. (2015). Brans ogretmenlerinin teknopedagojikegitim yeterlilikleri ile bireysel yenilikcilik duzeylerine iliskin gorusleri. Egitim ve Ogretim Arastirmalari Dergisi, 4(2).

Babbie, E. (1990). Survey Research Methods. Belmont, CA: Wadsworth Publishing.

Bowers, J., \& Stephens, B. (2011). Using technology to explore mathematical relationships: A framework for orienting mathematics courses for prospective teachers. Journal of Mathematics Teacher Education, 14, 285-304. http://dx.doi.org/10.1007/s10857-011-9168-x

Cohen, L., Manion, L., \& Morrison, K. (2003). Research Methods in Education. London: Routledge Falmer.

Cresswell, W. J. (2014). Research Design Qualitative, Quantitative and Mixed Methods Aproaches. 4th ed. Thousand Oaks, CA: Sage Publications.

Cuhadar, C., Bulbul, T., \& Ilgaz, G. (2013). Ogretmen adaylarinin bireysel yenilikcilik ozellikleri ile teknopedagojik egitim yeterlikleri arasindaki iliskinin incelenmesi. Ilkogretim Online, 12(3), 797-807.

Easton, V. J., \& McColl, H. J. (1997). Subjective Probability, Statistical Education through Problem Solving Statistics Glossary, 1(1). Retrieved March 15, 2015, Retrieved from

http://www.stats.gla.ac.uk/steps/glossary/probability.html

Gall, M. D., Borg, W. R., \& Gall, J. P. (1996). Educational research: An introduction. (6th ed.). New York: Longman 
Publishers.

Gur, H., \& Karamete, A. (2015). A Short Review of TPACK for Teacher Education. Educational Research and Reviews, 10(7), 777-789. http://dx.doi.org/10.5897/ERR2014.1982

Harris, J., Mishra, P., \& Koehler, M. (2009). Teachers' technological pedagogical content knowledge and learning activity types: curriculum-based technology integration reframed. Journal of Research on Technology in Education, 41(4), 393-416. http://dx.doi.org/10.1080/15391523.2009.10782536

Haslaman, T., Kuskaya-Mumcu, F., \& Usluel, Y. K. (2007). The integration of information and communication technologies in learning and teaching process: A lesson plan example. Education and Science, 32(146), 54-63.

Hofer, M., \& Harris, J. (2012). TPACK research with inservice teachers: Where's the TCK? In P. Resta (Ed.), Proceedings of Society for Information Technology \& Teacher Education International Conference 2012 (pp. 4704-4709). Chesapeake, VA: AACE.

Jamieson, R., Finger, G., \& Albion, P. (2010). Auditing the TK and TPACK confidence of pre-service teachers: Are they ready for the profession?. Australian Educational Computing, 25(1), 8-17.

Kabakci-Yurdakul, I. (2011). Ogretmen adaylarinin teknopedagojik egitim yeterliklerinin bilgi ve iletisim teknolojilerini kullanimları acisindan incelenmesi. Hacettepe Universitesi Egitim Fakultesi Dergisi (H. U. Journal of Education), 40, 397-408.

Kabakci-Yurdakul, I., \& Coklar, A. N. (2014). Modeling Preservice Teachers TPACK Competencies Based on ICT Usage. Journal of Computer Assisted Learning, 30, 363-376. http://dx.doi.org/10.1111/jcal.12049

Kabakci-Yurdakul, I., Odabasi, H. F., Kilicer, K., Coklar, A. N., Birinci, G., \& Kurt, A. A. (2012). The development, validity and reliability of TPACK-deep: A technological pedagogical content knowledge scale. Computers \& Education, 58, 964-977. http://dx.doi.org/10.1016/j.compedu.2011.10.012

Kaya, S., \& Dag, F. (2013). Sinif ogretmenlerine yonelik teknolojik pedagojik icerik bilgisi olcegi'nin Turkceye uyarlanmasi. Kuram ve Uygulamada Egitim Bilimleri, 13(1), 291-306.

Kaya, Z., Ozdemir, T. Y., Emre, G., \& Kaya, O. N. (2011). Bilisim teknolojileri ogretmen adaylarının teknolojik pedagojik alan bilgisi oz yeterlilik seviyelerinin belirlenmesi. Paper presented at the International Computer \& Instructional Technologies Symposium, Firat University, Elazig, Turkey.

Kazu, İ. Y., \& Erten, P. (2014). Teachers' Technological Pedagogical Content Knowledge Self-Efficacies. Journal of Education and Training Studies, 2(2), 126-144. http://dx.doi.org/10.11114/jets.v2i2.261

Koehler, M. J., \& Mishra, P. (2005). What happens when teachers design educational technology? The development of technological pedagogical content knowledge. Journal of Educational Computing Research, 32(2), 131-152. http://dx.doi.org/10.2190/0EW7-01WB-BKHL-QDYV

Koehler, M. J., \& Mishra, P. (2009). What is technological pedagogical content knowledge? Contemporary Issues in Technology and Teacher Education, 9(1), 60-70.

Kramarski, B., \& Michalsky, T. (2010). Preparing preservice teachers for self-regulated learning in the context of technological pedagogical content knowledge. Learning and Instruction, 20(5), 434-447. http://dx.doi.org/10.1016/j.learninstruc.2009.05.003

Kula, A. (2015). Ogretmen Adaylarinin Teknolojik Pedagojik Alan Bilgisi (TPAB) Yeterliliklerinin İncelenmesi: Bartin Universitesi Ornegi, Akademik Sosyal Arastırmalar Dergisi, 3(12), 395-412. http://dx.doi.org/10.16992/asos.615

Mazman, S. G., \& Kocak, U. Y. (2011). Bilgi ve iletisim teknolojilerinin ogrenme-ogretme sureclerine entegrasyonu: Modeller ve gostergeler. Egitim Teknolojisi Kuram ve Uygulama, 1(1), 62-79.

Mishra, P., \& Koehler, M. J. (2006). Technological Pedagogical Content Knowledge: A new framework for teacher knowledge. Teachers College Record, 108(6), 1017-1054. http://dx.doi.org/10.1111/j.1467-9620.2006.00684.x

Ozturk, E. (2013) Sinif Ogretmeni Adaylarinin Teknolojik Pedagojik Alan Bilgilerinin Bazi Degiskenler Acisindan Degerlendirilmesi. Usak Universitesi Sosyal Bilimler Dergisi, 6(2), 223-228.

Robson, C., \& McCartan, K. (2016). Real World Research: A Resource for Users of Social Research Methods in Applied Settings (4th ed.). London: John Wiley \& Sons.

Sad, N. S., Acikgul, K., \& Delican, K. (2015). Egitim Fakultesi Son Sinif Ogrencilerinin Teknolojik Pedagojik Alan Bilgilerine (TPAB) Iliskin Yeterlilik Algilari. Kuramsal Egitimbilim Dergisi, 8(2), 204-235.

Sancar-Tokmak, H., Yavuz-Konokman, G., \& Yanpar-Yelken, T. (2013). Mersin Universitesi okul oncesi ogretmen 
adaylarinin teknolojik pedagojik alan bilgisi (TPAB) ozguven algilarinin incelenmesi. Ahi Evran Universitesi Kirsehir Egitim Fakultesi Dergisi, 14(1), 35-51.

Schmidt, D. A., Baran, E., Thompson, A. D., Mishra, P., Koehler, M. J., \& Shin, T. S. (2009). Technological Pedagogical Content Knowledge (TPACK). Journal of Research on Technology in Education, 42(2), 123-149. http://dx.doi.org/10.1080/15391523.2009.10782544

Shulman, L. S. (1896). Those who understand: Knowledge growth in teaching. Educational Researcher, 15(2), 4-14. (AERA Presidential Address). http://dx.doi.org/10.3102/0013189X015002004

Simsek, O., Demir, S., Bagceci, B., \& Kinay, İ. (2013). Ogretim elemanlarinin teknopedagojik egitim yeterliliklerinin cesitli degiskenler acisindan incelenmesi. Ege Egitim Dergisi, 1(14), 1-23.

Usluel, K. Y., Ozmen, B., \& Celen, F. K. (2015). BíT'in Ogrenme Ogretme Surecine Entegrasyonu ve Teknolojik Pedagojik Icerik Bilgisi Modeline Elestirel Bir Bakis. Egitim Teknolojisi Kuram ve Uygulama, 5(1).

Voogt, J., Fisser, P., Roblin, P. T., \& Braakt, J. (2013). Technological pedagogical content knowlede-a review of the literature. Journal of Computer Assisted Learning, 29(2), 109-121. http://dx.doi.org/10.1111/j.1365-2729.2012.00487.x

Yavuz-Konokman, G., Yanpar-Yelken, T., \& Sancar-Tokmak, H. (2013). Sinif ogretmeni adaylarinin TPAB’lerine iliskin algilarinin cesitli degiskenlere gore incelenmesi: Mersin Universitesi ornegi. Kastamonu Egitim Dergisi, 21(2), 665-684.

Yildirim, A., \& Simsek, H. (2004). Nitel Arastirma Yontemleri. Ankara: Seckin Yayinlari.

Yilmaz, M. (2007). Sinif ogretmeni yetistirmede teknoloji egitimi. Gazi Egitim Fakultesi Dergisi, 27(1), 155-167.

\section{Notes}

Note 1. The partial content of this article has been presented at the II. International Eurasian Educational Research Congress, Hacettepe University, Turkey.

\section{$(c)$ EY}

This work is licensed under a Creative Commons Attribution 3.0 License. 